P-ISSN 2580 - 7781

E-ISSN $2615-3238$

\title{
PENTINGNYA PENDIDIKAN KARAKTER UNTUK MEMBANGUN GENERASI EMAS INDONESIA
}

\section{THE IMPORTANCE OF CHARACTER EDUCATION FOR BUILDING INDONESIAN GOLD GENERATION}

\author{
Yulianti \\ Program Studi Pendidikan Guru Sekolah Dasar, Kampus Daerah Cibiru, \\ Universitas Pendidikan Indonesia \\ E-mail: yuliantiyya@upi.edu
}

\begin{abstract}
ABSTRAK
Penelitian ini bertujuan untuk memberi gambaran mengenai pendidikan karakter untuk membangun generasi emas Indonesia. Metode penelitian yang dilakukan ialah penelitian deskriptif-kualitatif yang berdasarkan para ahli atau penelitian terdahulu serta mengumpulkan data dari beberapa jurnal ilmiah dan buku. Metode ini dilakukan dengan membaca berbagai sumber kemudian dihubungkan dengan topik yang dibahas untuk kemudian disampaikan kembali dalam bentuk deskripsi. Pendidikan dalam kehidupan manusia merupakan suatu hal yang sangat penting, karena pendidikan dapat menjadi tonggak adanya perubahan, mewujudkan bangsa yang cerdas, kompeten dan memiliki potensi moral dengan rasa berbudaya. Pendidikan tidak hanya semata-mata mentransfer ilmu, akan tetapi mengembangkan nilai-nilai luhur terutama karakter. Oleh karena itu, pendidikan menjadi kebutuhan pokok bagi setiap anak di Indonesia. Bangsa Indonesia akan memasuki generasi emas pada tahun 2045 yang bisa menjadi bonus demografi paling berharga, sehingga setiap anak harus terus diarahkan agar dapat memiliki kualitas diri yang baik, produktif, dan berkarakter.
\end{abstract}

Kata Kunci: Pendidikan, Generasi emas, Pendidikan karakter.

\begin{abstract}
This study aims to provide an overview of character education to build Indonesia's golden generation. The research method used is descriptive-qualitative research based on experts or previous research and collects data from several scientific journals and books. This method is done by reading various sources and then connecting them with the topics discussed and then conveying them again in the form of descriptions. Education is a very important thing for human life, because education can be a milestone for change, creating a nation that is smart, competent and has moral potential with a sense of culture. Education is not only about transferring knowledge, but also developing noble values, especially character. Therefore, education is a basic requirement for every child in Indonesia. The Indonesian nation will enter the golden generation in 2045 which can be the most valuable demographic bonus, so that every child must continue to be directed so that they can have good, productive, and character qualities.

Keywords: Education, Golden generation, Character education.
\end{abstract}

\section{PENDAHULUAN}

Pendidikan secara etimologi berawal dari bahasa Yunani dengan kata pedagogie yang artinya memberikan bimbingan kepada anak. Sedangkan, dari bahasa Inggris berawal dengan kata to educate yang artinya membangun 
intelektual dan memperbaiki moral. Secara bahasa, pendidikan berarti memberikan bimbingan kepada anak oleh seseorang atau orang yang lebih dewasa untuk memberi pengajaran, membangun intelektual dan memperbaiki moral. Bimbingan yang diberikan kepada anak dapat dilakukan secara formal seperti sekolah ataupun dilakukan secara informal seperti dalam keluarga atau masyarakat. (Sholichah, 2018)

Pendidikan dalam kehidupan manusia merupakan suatu hal yang sangat penting, karena pendidikan dapat mencerdaskan kehidupan bangsa, membentuk bangsa yang bermartabat, dan mencetak generasi unggul. Pendidikan juga dapat diartikan sebagai upaya untuk memanusiakan manusia, yakni merupakan makna hakiki dalam pendidikan untuk menemukan potensi diri dengan menyesuaikan setiap bakat dan minat serta kebutuhan yang dimiliki setiap anak agar menjadi lebih manusiawi. Pendidikan tidak hanya berfokus pada ilmu pengetahuan, tetapi berbasis pengembangan diri, sikap dan perilaku yang baik agar dapat menjalankan kehidupan dengan intelektual dan karakter yang diperoleh dari pengalaman belajar.

Membangun karakter menjadi salah satu tujuan dari pendidikan yang termuat dalam Undang-Undang Nomor 20 Tahun 2003 "Pendidikan ialah usaha sadar dan terencana sebagai upaya mewujudkan proses pembelajaran dan suasana belajar yang secara aktif mengembangkan potensi diri peserta didik agar mempunyai kekuatan spiritual keagamaan, akhlak mulia, kecerdasan, kepribadian dan pengendalian diri, serta keterampilan yang diperlukan dirinya, masyarakat, bangsa dan negara”. Oleh karena itu, pendidikan karakter sangatlah penting dibangun sejak dini, pendidikan karakter harus dibina dan terus dikembangkan baik melalui pendidikan formal ataupun non-formal.

Bangsa Indonesia akan mempunyai bonus demografi (demographic divident) pada tahun 2045, yaitu memiliki jumlah masyarakat yang sedang dalam usia produktif (15-64 tahun) terbanyak sepanjang sejarah. Masyarakat Indonesia yang sedang dalam usia produktif tersebut apabila dapat dimanfaatkan dan dikelola dengan baik bisa menjadi bonus demografi yang berharga. Dalam rangka membangun generasi emas Indonesia diperlukan pembangunan pendidikan 
P-ISSN 2580 - 7781

E-ISSN 2615 - 3238

terutama karakter, agar mempunyai pola pikir dan perilaku yang berlandaskan moral sebagai salah satu usaha membangun bangsa.

Generasi emas adalah sekelompok orang yang diharapkan menjadi generasi penerus bagi bangsa dan negaranya sehingga harus terus diarahkan agar memiliki kualitas diri yang baik, produktif, dan berkarakter. Sesuai dengan pemikiran Ki Hajar Dewantara bahwa pendidikan ialah proses untuk mengembangkan budi pekerti (karakter) dan pikiran (intellect) anak (Yusuf, 2016). Pendidikan karakter merupakan aspek penting untuk meningkatkan daya saing bangsa, dan dengan generasi emas yang unggul diharapkan dapat membawa perubahan signifikan menjadi lebih baik terhadap kemajuan bangsa dan negara.

\section{METODE PENELITIAN}

Metode penelitian yang digunakan adalah metode penelitian yang termasuk ke dalam penelitian deskriptif yaitu mengumpulkan data-data relevan bersifat kepustakaan. Sumber kepustakaan yang peneliti gunakan pada penelitian ini yaitu buku, jurnal ilmiah berupa artikel, skripsi, dan sumber dari internet, berdasarkan pendapat para ahli terdahulu. Metode ini dilakukan dengan membaca berbagai sumber kemudian dihubungkan dengan topik yang dibahas untuk kemudian disampaikan kembali dalam bentuk deskripsi.

\section{HASIL DAN PEMBAHASAN}

Kehidupan manusia tidak dapat lepas dari pendidikan karena pendidikan tentunya dapat mencetak martabat dan arah kehidupan manusia. Segala upaya dalam meningkatkan keberhasilan pendidikan dilakukan oleh suatu bangsa dan negara agar memiliki kualitas manusia yang unggul. Salah satu aspek yang dianggap memiliki peranan penting dalam upaya meningkatkan keberhasilan pendidikan adalah dengan pendidikan karakter, karena dengan sebuah pendidikan karakter membentuk manusia yang bermoral dan berbudaya.

Pendidikan karakter akan menjadi upaya peningkatan kualitas manusia sekaligus sebagai salah satu solusi permasalahan akan kemerosotan moral, karakter menentukan setiap arah dalam mengambil keputusan dan tingkah laku serta menentukan kualitas moral generasi muda. Oleh sebab itu, karakter yang 
dibangun ialah berlandaskan moral yang kokoh sehingga dapat menjadi ujung tombak perbaikan karakter yang secara nyata diimplementasikan dalam setiap kehidupan, sehingga Indonesia dapat membentuk generasi emas.

Proses pendidikan karakter harus ditanamkan dan dilakukan sejak dini. Nilai-nilai karakter ditanamkan kepada generasi emas dengan pemberian dan penguatan yang dilakukan secara berulang, karena karakter seseorang akan tumbuh melalui proses pembiasaan yang dilakukan. Pendidikan karakter yang diharapkan dari generasi emas ialah dapat memiliki pola pikir dan tingkah laku berlandaskan moral yang kokoh, kecerdasan yang tinggi, dan sikap kompetitif untuk visi yang cemerlang di masa depan.

Menurut Kementerian Pendidikan dan Kebudayaan (2016) nilai-nilai dalam pendidikan karakter meliputi 5 nilai utama, yakni:

1. Religius, yakni mencakup dimensi hubungan antar manusia, hubungan dengan Tuhan dan hubungan dengan alam semesta. Penjabaran nilai religius yang lebih rinci dapat meliputi menghargai setiap agama dan juga kepercayaan masingmasing, anti kekerasan dan penindasan, toleransi, cinta damai, bekerja sama dan tidak memaksakan kehendak.

2. Nasionalis, yakni nilai karakter yang terlihat dalam cara berperilaku, bersikap dan berpikir yang menggambarkan kesetiaan. Memiliki rasa yang tinggi akan kepentingan bangsa diatas kepentingan sendiri, cinta tanah air, rela berkorban, dan toleransi terhadap keragaman budaya.

3. Mandiri, yakni nilai karakter untuk tidak bergantung terhadap orang lain dalam berperilaku dan bersikap. Menggunakan pikiran, tenaga, waktu untuk mewujudkan harapan dan cita-cita dengan tidak mengandalkan orang lain. Penjabaran nilai mandiri yang lebih rinci ialah etos kerja (kerja keras), tangguh, profesional dan berani.

4. Gotong royong, merupakan nilai karakter yang menggambarkan sikap saling bahu membahu dan menghargai kerja sama dalam menyelesaikan pekerjaan. Nilai karakter gotong royong dapat berupa solidaritas, musyawarah, mufakat dan sikap kerelawanan. 
5. Integritas, yakni berupaya membangun sikap dapat dipercaya dalam melakukan suatu tindakan maupun perkataan. Mempunyai komitmen dan kesetiaan terhadap nilai-nilai moral dan kemanusiaan. Nilai karakter integritas dapat terlihat seperti jujur, komitmen tinggi, dan tanggung jawab.

Keberhasilan pendidikan dipengaruhi oleh beberapa faktor dan dapat dilakukan melalui berbagai cara, baik itu di sekolah sebagai pendidikan formal ataupun di lingkungan rumah sebagai pendidikan non-formal. Sesuai dengan pemikiran Ki Hajar Dewantara, "Tri Pusat Pendidikan" ialah sekolah, keluarga dan masyarakat merupakan pendukung penyelenggaraan pendidikan. Membangun pendidikan karakter bukan hanya dilakukan di sekolah, tetapi dilakukan dalam kehidupan sehari-hari. Membangun karakter siswa mengenai nilai-nilai moral, etika, dan rasa berbudaya yang baik merupakan usaha dan tanggung jawab dari semua pihak.

Pertama, keluarga terutama orang tua menjadi peran penting bagi membangun karakter generasi emas, karena orang tua adalah teladan untuk anakanaknya sehingga segala perilaku orang tua akan banyak mempengaruhi perkembangan anak. Keluarga dan orang tua adalah pendidikan utama dan pertama bagi anak sehingga kebiasaan yang membentuk karakter diajarkan pertama kali dalam lingkungan keluarga (Hyoscyamina, 2011). Orang tua harus meningkatkan implementasi pendidikan karakter yang bersifat informal dalam lingkungan keluarga dengan norma-norma dan moral yang sesuai. Fungsi kontrol orang tua pun harus dilakukan secara efektif dan efisien.

Kedua, sekolah terutama guru menjadi peran penting dalam membangun karakter generasi emas. Peran guru di sekolah tidak hanya memberikan pengetahuan tetapi dituntut untuk menjadi model atau panutan dalam bersikap. Guru memposisikan diri dengan bijak agar dapat memberikan pendidikan yang memanusiakan, yaitu pendidikan yang dapat memberikan pencerahan mengenai hakikat manusia itu sendiri. Pendidikan yang memanusiakan juga berarti pendidikan yang menjunjung tinggi nilai solidaritas dan cinta kasih. Guru harus mampu menyusun strategi pembelajaran yang tepat, pembelajaran kreatif dan inovatif yang menekankan pada pemecahan masalah, pengembangan komunikasi 
dan kemampuan untuk hidup antar sesama manusia agar siswa dapat mengembangkan nilai-nilai karakter.

Pemerintah mengeluarkan program Penguatan Pendidikan Karakter (PPK) yang merupakan suatu usaha sebagai pembudayaan karakter di sekolah, bertujuan untuk membangun pendidikan yang bermoral dan berkualitas di seluruh Indonesia secara merata. Penerbitan Peraturan Presiden Nomor 87 Pasal 2 Tahun 2017 tentang Penguatan Pendidikan Karakter (PPK) memiliki tujuan:

1. Membangun pendidikan karakter yang baik terhadap peserta didik sebagai persiapan untuk generasi emas Indonesia tahun 2045 mengahadapi berbagai dialektika perubahan di masa depan.

2. Penyelenggaraan pendidikan yang berorientasi pada pendidikan karakter dengan dukungan berbagai pihak baik melalui pendidikan formal, informal, dan non-formal dengan menyelipkan keberagaman budaya Indonesia.

3. Membangun potensi dan kompetensi peserta didik, pendidik, tenaga kependidikan, lingkungan keluarga dan masyarakat dalam pengimplementasian Penguatan Pendidikan Karakter.

Ketiga, masyarakat merupakan lingkungan yang juga mempunyai peran dalam membangun pendidikan karakter. Masyarakat sebagai lingkungan yang mempunyai pengaruh besar dalam upaya mencerdaskan generasi bangsa, sesuai dengan Undang-Undang Nomor 20 Tahun 2003 yang memuat hak dan kewajiban masyarakat berbunyi "Masyarakat berhak berperan serta dalam pelaksanaan, perencanaan, dan pengawasan evaluasi program pendidikan." Masyarakat dalam pasal tersebut tertuju pada warga negara Indonesia yang memiliki perhatian dan peranan dalam penyelenggaraan pendidikan.

Masyarakat juga tak kalah pentingnya sebagai contoh panutan dan pendorong keberhasilan dalam menerapkan kebiasaan-kebiasaan karakter yang baik. Masyarakat menjadi bagian dalam sebuah pendidikan juga harus memperlihatkan tuntunan lingkungan yang baik bukan tuntunan yang dapat merusak tatanan pendidikan, memberikan tuntunan untuk bersikap sesuai dengan nilai-nilai moral. Masyarakat harus mendukung terciptanya pembudayaan dan penanaman karakter yang baik, agar generasi emas tumbuh menjadi perilaku 
P-ISSN 2580 - 7781

E-ISSN $2615-3238$

sesuai dengan yang diharapkan (Abi, 2017).

Generasi emas dikenal sebagai agent of change, yaitu menjadi pembawa perubahan untuk kemajuan bangsa yang akan datang. Pendidikan karakter menjadi salah satu aspek untuk peningkatan kualitas pendidikan. Pentingnya pendidikan karakter bagi generasi emas diharapkan mampu membawa perubahan akan keberhasilan pendidikan di Indonesia. Harapan dan cita-cita tersebut tidak akan terwujud apabila tidak adanya usaha dan kerjasama dari semua pihak, baik itu antar pemegang kebijakan dan pelaku kebijakan. Oleh sebab itu, untuk menciptakan generasi emas yang berkarakter harus dimulai dari kerjasama para pendidik.

Kita semua menyadari, bahwa suatu bangsa akan dapat maju dan mengejar ketertinggalan dari bangsa lain hanya dengan sebuah pendidikan. Peran pendidikan yang berdasarkan karakter dan jati diri bangsa akan menciptakan generasi emas yang memiliki etika dan berbudaya. Generasi emas akan mencetak kualitas manusia yang unggul di masa depan, sebagaimana yang telah dicitacitakan bersama, membangun generasi emas dengan pendidikan karakter merupakan bagian penting dalam memajukan pendidikan Indonesia.

\section{KESIMPULAN}

Pendidikan karakter pada dasarnya adalah upaya dalam mewujudkan pendidikan yang dapat membentuk seorang individu memiliki sikap dan perilaku yang bermoral. Karakter tersebut dibentuk melalui pembiasaan yang dilakukan secara berulang-ulang. Oleh sebab itu, pendidikan karakter harus ditanamkan sejak dini karena dengan begitu bangsa Indonesia dapat mencetak generasi emas yang unggul. Pendidikan karakter dilakukan melalui berbagai lembaga seperti keluarga, sekolah dan lingkungan masyarakat. Keluarga sebagai tempat utama dan pertama dalam membentuk pendidikan karakter yang baik. Sekolah khususnya peran guru tidak hanya mentransfer ilmu tetapi menjadi teladan dalam mengimplementasikan pendidikan karakter. Masyarakat sekitar memiliki peran dalam mengembangkan dan memotivasi pendidikan karakter. Generasi emas menjadi generasi yang diharapkan bagi masa depan bangsa Indonesia harus terus diarahkan dan diberikan bimbingan agar dapat menjadi manusia yang unggul dan 
sebagai pembawa perubahan bagi bangsa Indonesia.

\section{DAFTAR PUSTAKA}

Abi, A. R. (2017). Paradigma Membangun Generasi Emas Indonesia Tahun 2045. Jurnal Ilmiah Pendidikan Pancasila Dan Kewarganegaraan, 2(2), 8590. https://doi.org/10.17977/um019v2i22017p085

Amran, A., Perkasa, M., Jasin, I., Satriawan, M., \& Irwansyah, M. (2019). Model Pembelajaran Berbasis Nilai Pendidikan Karakter Untuk Generasi Indonesia Abad 21. Lentera Pendidikan: Jurnal Ilmu Tarbiyah Dan Keguruan, 22(2), 233. https://doi.org/10.24252/lp.2019v22n2i5

Darman, R. A. (2017). Mempersiapkan Generasi Emas Indonesia Tahun 2045 Melalui Pendidikan Berkualitas. Edik Informatika, 3(2), 73-87. https://doi.org/10.22202/ei.2017.v3i2.1320

Hasnawati. (2016). Membangun generasi emas melalui perspepktif pendidikan karakter. 247-254

Hyoscyamina, D. E. (2011). Peran Keluarga Dalam Membangun Karakter Anak. Jurnal Psikologi Undip, 10(2), 144-152

Sholichah, A. S. (2018). Teori-Teori Pendidikan Dalam Al-Qur'an. Edukasi Islami : Jurnal Pendidikan Islam, 7(01), 23. https://doi.org/10.30868/ei.v7i01.209

Yusuf, M. (2016). Pendidikan Karakter Menuju Generasi Emas 2045. Inovasi Pendidikan, 2(4), 9-16 